\title{
$\mathrm{DC}$ 스퍼터법과 비대칭 바이폴라 펄스 $\mathrm{DC}$ 스퍼터법으로 증착된 $\mathrm{TiN}$ 코팅막의 물성 비교연구
}

\author{
전성용*
}

목포대학교 신소재공학과

\section{A Comparative Study of TiN Coatings Deposited by DC and Pulsed DC Asymmetric Bipolar Sputtering}

\author{
Sung-Yong Chun* \\ Department of Advanced Materials Science and Engineering, Mokpo National University, \\ Mokpo 534-729, Korea
}

(Received September 20, 2011 ; revised October 24, 2011 ; accepted October 28, 2011)

\begin{abstract}
This work investigated the effect of duty cycle and pulse frequency on the microstructures and properties of titanium nitride thin films deposited by asymmetric bipolar pulsed DC sputtering system. Oscilloscope traces of the I-V waveforms indicate high power and high current density outputs during the asymmetric bipolar pulsed mode. The grain size decreases with decreasing duty cycle. The duty cycle has a strong influence not only on the microstructural properties but also on the mechanical properties of titanium nitride films. Comparing with the continuous DC sputtering, the titanium nitride films prepared by pulsed DC asymmetric bipolar process exhibit better properties.
\end{abstract}

Keywords: Duty cycle, Pulse frequency, Asymmetric bipolar, Pulsed sputtering

\section{1. 서 론}

$\mathrm{TiN}$ 코팅막은 열적·화학적으로 안정하며 높은 내 산화성과 내마모율 그리고 낮은 마찰계수를 갖기 때문에 반도체 소자의 확산 베리어층과 금속공구의 내마모 코팅 소재로의 응용에 많은 연구가 이루어 지고 있다 ${ }^{1-3)}$. 또한 $\mathrm{TiN}$ 은 순수한 $\operatorname{Ti}(40 \sim 50 \mu \Omega$-cm) 보다 낮은 전기저항 $(18 \sim 25 \mu \Omega-\mathrm{cm})$ 을 갖기 때문에 차세대 NAS계 연료전지의 전극소재로서 최근 주 목받고 있다 ${ }^{4,5)}$. 일반적으로 $\mathrm{TiN}$ 코팅막을 제작하 는 공정에는 $\mathrm{CAD}$ (Cathodic Arc Deposition), EB (Electron Beam)법과 반응성 스퍼터링 등의 다양한 방법이 보고되고 있다 ${ }^{6,7}$. 그러나 반도체 및 전지분 야에서의 응용을 위해서는 높은 증착율을 가지면서

*Corresponding author. E-mail : sychun@mokpo.ac.kr
박막 특성을 우수하게 제어할 수 있는 기술을 필요 로 하는데 최근에 이러한 기술로서 비대칭 바이폴 라 펄스 $\mathrm{DC}$ 스퍼터링법이 주목받고 있다.

최근에, 펄스 $\mathrm{DC}$ 스퍼터링법은 성막 중 아크가 거의 발생하지 않고 특히 기판과 코팅막의 부착력 이 우수할 뿐만 아니라 부도성의 타겟도 이용할 수 있기 때문에 부전도성 재료를 만들기 위해 널리 이 용되고 있다. 일반적인 $\mathrm{DC}$ 스퍼터링의 저밀도 플 라즈마와 비교하여 펄스 $\mathrm{DC}$ 스퍼터링법은 높은 이 온 플럭스와 넓은 이온 에너지 분포를 갖는다고 보 고되고 있담. 펄스 플라즈마의 이온 에너지와 이 온 플럭스의 증가는 $\mathrm{TiN}$ 코팅막의 조성, 조직계수, 미세구조와 물성 등에 커다란 영향을 끼치게 된다. 비대칭 바이폴라 펄스 $\mathrm{DC}$ 스퍼터링법은 타겟에 인가되는 펄스의 형태를 조절함으로써 공정 및 증 착되는 코팅막의 특성을 조절할 수 있다. 듀티 싸 
이클은 양의 펄스 및 음의 펄스 유지시간의 합에 대한 음의 펄스 유지시간의 비로 정의되고 듀티 싸 이클과 펄스 주파수를 조절하여 아크가 발생하지 않는 안정한 공정을 이룰 수 있다. 또한 그와 동시 에 빠른 증착 속도를 갖는 양질의 코팅막을 제조할 수 있는 방법이다. 그러나 현재까지 국내에서는 비 대칭 바이폴라 펄스 $\mathrm{DC}$ 마그네트론 스퍼터링법을 이용한 코팅막에 대한 연구는 $\mathrm{ZnO}$ 과 $\mathrm{AlN}$ 에 국한 되어 있을 뿐이고 이들 논문에서도 펄스 플라즈마 변수가 코팅막의 결정구조에 미치는 영향과 코팅 중 듀티 싸이클과 펄스 주파수 공정변수가 결정립 크기의 미세화나 코팅막의 치밀화에 미치는 영향에 대해 보고된 바 없다 ${ }^{9,10)}$.

본 연구에서는 코팅장비에 따른 $\mathrm{TiN}$ 코팅막의 물 성비교를 위해 종래의 연속적인 $\mathrm{DC}$ 스퍼터와 함께 비대칭 바이폴라 펄스 $\mathrm{DC}$ 스퍼터를 이용하여 $\mathrm{TiN}$ 코팅막을 제조하였다. 특히 비대칭 바이폴라 펄스 $\mathrm{DC}$ 전원을 이용하여 고이온화 및 고밀도 플라즈마 를 생성하였다. 그리고 기판바이어스 전압 인가에 따른 이온포격효과가 TiN 코팅막의 몰폴러지, 결정 립 크기와 같은 미세구조적 변화에 미치는 영향을 관찰하였다. 또한 잔류응력과 같은 구조적 물성 변 화와 나노 경도와 같은 기계적 특성에 미치는 결과 에 대해 고찰하였다.

\section{2. 실험방법}

본 실험에서는 $\mathrm{Si}(100)$ 기판을 사용하였고, 기판 표면의 불순물을 제거하기 위하여 초음파 세척기를 이용하여 아세톤과 에틸 알코올에서 각각 10 분간 세척을 실시한 후 건조하였다. 본 실험에서 사용한 코팅장비는 비대칭 펄스 $\mathrm{DC}$ 반응성 마그네트론 스 퍼터링 장치로 출발원료로는 직경 $3 "$, 두께 $1 / 4 "$, 순 도 $99.995 \%$ 의 $\mathrm{Ti}$ 타겟을 사용하였다. TiN 코팅막의 증착을 위해 초고순도의 $\mathrm{N}_{2}$ 와 $\mathrm{Ar}$ 가스를 사용하였 고 $\mathrm{Ar}$ 과 $\mathrm{N}_{2}$ 가스의 분압조절은 $\mathrm{MFC}$ (Mass Flow Controller)를 이용하여 조절하였다. 증착시 기판과 타겟간 거리는 $60 \mathrm{~mm}$ 로 유지하고, 균일한 증착을 위해 기판을 약 $10 \mathrm{rpm}$ 의 속도로 회전시켰다. $\mathrm{TiN}$ 코팅막은 $\mathrm{Ar}$ 과 $\mathrm{N}_{2}$ 를 적절히 혼합한 분위기에서 증
착하였다. 챔버의 초기압력은 로터리 펌프와 터보 분자펌프를 사용하여 약 $4.0 \times 10^{-4} \mathrm{~Pa}$ 까지 배기시켰 으며 진공도의 측정은 이온 게이지와 바라트론게이 지를 이용하였다. 증착 전에 타겟과 기판을 세척하 기 위해 $\mathrm{Ar}$ 플라즈마를 발생시켜 처리하였다.

코팅막의 물성 비교 및 분석을 위해 종래의 DC 전원과 펄스 $\mathrm{DC}$ 전원을 이용하여 $\mathrm{TiN}$ 코팅막을 제 작하였으며 표 1 에 자세한 비대칭 펄스 플라즈마 성막 조건을 타내었다. 또한 얻어진 나노결정질 TiN 코팅막의 결정상분석, 집합조직계수, 우선배향성 및 반가폭 등의 분석을 위해 PAN analytical사의 X-ray Diffractometer(XRD)를 사용하였고 3차원적 몰폴러 지와 표면 거칠기 측정을 위해 Thermo-Microscope 사의 Auto Probe Atomic Force Microscopy(AFM) 을 이용하였다. 또한 코팅막의 나노 경도 측정은 MTS System사의 정밀경도시험기인 나노인덴테이터 를 이용하였다. 경도는 Berkovich 다이아몬드 압자 를 이용하여 16 번의 실험을 통한 평균값으로 구하 였다. 나노인덴터 측정 간격은 이미 실행된 경도 측 정 팁에 영향을 받지 않기 위해 $10 \mu \mathrm{m}$ 이상을 유 지하였다. 또한 모재에 영향을 끼치지 않는 범위에 서 경도를 측정하기 위해 압입 깊이는 코팅막의 두 께의 $10 \%$ 정도로 고정하였다.

\section{3. 실험결과}

\section{1 비대칭 바이폴라 펄스의 전류-전압특성}

나노결정질 $\mathrm{TiN}$ 코팅 중 타겟에 인가되는 비대칭 바이폴라 펄스의 듀티 싸이클을 디지털스코프를 이 용하여 실시간 측정한 전류 및 전압의 시간특성을 그림 1 에 나타내었다. 일반적으로 바이폴라 펄스 $\mathrm{DC}$ 전원발생장치는 대칭형과 비대칭형 펄스 듀티 싸이클의 발생이 모두 가능한데 대칭형의 경우 펄 스 전압은 양극, 음극 모두 동일한 반면, 비대칭형 의 경우 양극보다 음극의 펄스 전압이 높다. 또한 펄스의 온-오프 발생시간의 다양한 조절도 가능하 다. 본 실험에서는 비대칭 바이폴라 펄스 타입의 $\mathrm{DC}$ 전원발생장치를 이용하였는데 이는 타겟전압이 양극에서 음극으로 다시 음극에서 양극으로 주기적 으로 전환되기 때문에 질화물과 산화물과 같은 부

Table 1. Conditions for deposition of TiN coatings by DC and pulsed DC sputtering

\begin{tabular}{|l|c|c|c|c|}
\hline Condition & 1 & 2 & 3 & 4 \\
\hline Target & DC $500 \mathrm{~W}$ & pulsed DC $500 \mathrm{~W}$ & pulsed DC 500 W & pulsed DC 500 W \\
\hline Pulse frequency & & $5 \mathrm{KHz}$ & $25 \mathrm{KHz}$ & $50 \mathrm{KHz}$ \\
\hline Duty cycle & & $95 \%$ & $75 \%$ & $50 \%$ \\
\hline Substrate bias & DC $-100 \mathrm{~V}$ & DC $-100 \mathrm{~V}$ & DC $-100 \mathrm{~V}$ & DC $-100 \mathrm{~V}$ \\
\hline
\end{tabular}




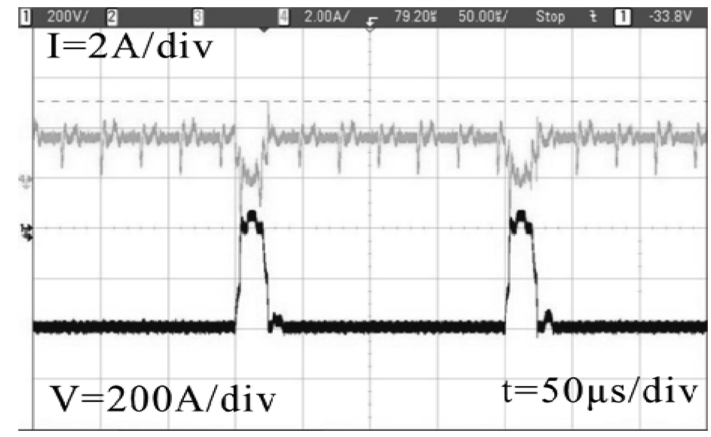

(a)

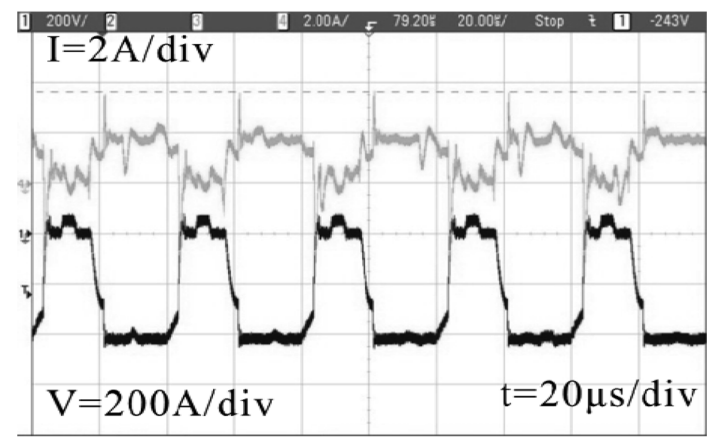

(b)

Fig. 1. Time behaviors of voltage and current of bipolar pulsed modes at (a) condition 2 and at (b) condition 3 .

도성 화합물의 코팅에도 이상적이기 때문이다 ${ }^{11)}$. 또 한 표 1에서 듀티 싸이클 $95 \%$ 와 펄스 주파수 $5 \mathrm{KHz}$ 를 인가한 경우(condition 2), 양의 펄스 인가시간은 약 $20 \mu \mathrm{s}$ 로 음의 펄스 인가시간 약 $180 \mu \mathrm{s}$ 보다 상 대적으로 짧은 시간 동안 인가하였는데 이는 실질 적인 코팅에 소요되는 시간의 확보와 종래의 $\mathrm{DC}$ 스퍼터링법과 같은 음의 펄스 인가만으로 스퍼터링 시 발생되는 대표적인 문제점인 아킹과 타겟 포이 즈닝의 발생을 억제하기 때문이다. ${ }^{12)}$

\section{2 성막율}

그림 2에 듀티 싸이클과 펄스 주파수 변화에 따 른 TiN 코팅막의 성막율을 나타내었다. 본 실험결 과에서 흥미로운 점은 듀티 싸이클 및 펄스 주파수 와 같은 펄스 플라즈마의 변수와 상관없이 종래의 $\mathrm{DC}$ 스퍼터링법보다 비대칭 펄스 $\mathrm{DC}$ 스퍼터링법으 로 제작한 $\mathrm{TiN}$ 코팅막의 성막율이 낮다는 점이다. 예를 들면 종래의 DC 스퍼터링법으로 코팅한 경우 성막율은 $1.4 \mu \mathrm{m} / \mathrm{h}$ 이었으나 듀티 싸이클 $50 \%$ 와 펄 스 주파수 $50 \mathrm{KHz}$ 에서 코팅한 경우 $\mathrm{TiN}$ 코팅막의 성막율은 $0.4 \mu \mathrm{m} / \mathrm{h}$ 로 약 $28 \%$ 감소함을 알 수 있다. 또한 TiN 코팅막의 성막율은 듀티 싸이클과 펄스 주파수와 같은 플라즈마 공정변수에 크게 의존함을 알 수 있다.

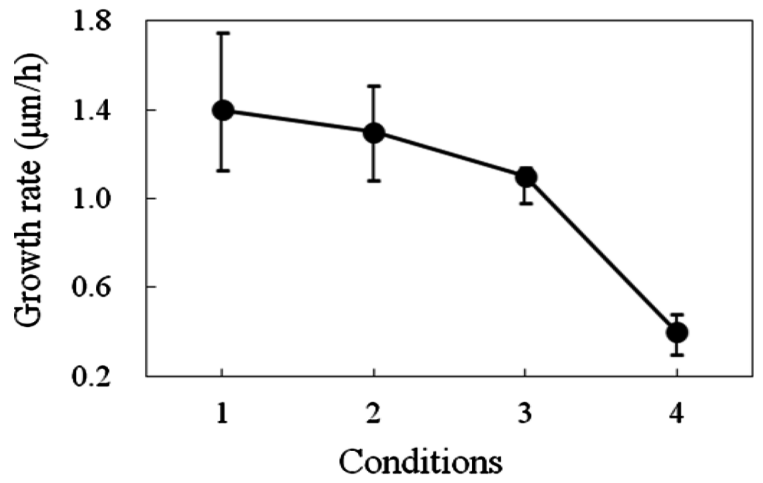

Fig. 2. The growth rates of TiN films deposited by DC and pulsed DC sputtering.

그 원인으로서는 우선 (1) 듀티 싸이클의 감소에 따른 비대칭 펄스 $\mathrm{DC}$ 스퍼터링법의 경우 종래의 $\mathrm{DC}$ 스퍼터링법에 비해 양의 스퍼터 전압인가에 따 른 실질적인 음의 스퍼터 인가시간의 감소와 (2) 양 과 음으로 반복되는 스퍼터 전압의 전환시 동반되 는 실질적인 시간의 감소를 들 수 있다 ${ }^{13)}$. 또한 반 응성 스퍼터링의 경우 기판과 음극 타겟 표면 사이 의 반응성 가스가 존재하기 때문에 (3) 반응가스와 타겟과의 강한 상호작용으로 타겟 표면에 절연막이 형성되어 이에 따른 스퍼터율 감소가 낮은 성막율 에 기인한다고 사료된다. 그밖에 (4) 펄스 주파수의 증가에 의해서도 성막율은 감소할 수 있다. 펄스 주 파수 $20 \mathrm{KHz}$ 에서 제작한 $\mathrm{CrN}$ 코팅막의 성막율은 $2 \mathrm{KHz}$ 에 비해 약 $65 \%$ 까지 감소한다는 연구결과도 보고되고 있다 ${ }^{13)}$. 따라서 본 연구에서 얻어진 성막 율의 감소는 듀티 싸이클, 스퍼터율의 감소 및 펄 스 주파수 등의 복합적인 영향에 따른 결과라고 사 료된다.

\section{3 결정립 크기}

그림 3에 $\mathrm{DC}$ 스퍼터법 및 비대칭 펄스 $\mathrm{DC}$ 스퍼 터링법으로 제작한 $\mathrm{TiN}$ 코팅막 (111)면의 X선 회절 분석 피크의 반가폭과 결정립 크기변화를 나타냈다. 코팅막의 결정립 크기는 $\mathrm{X}$ 선 회절분석 피크의 반

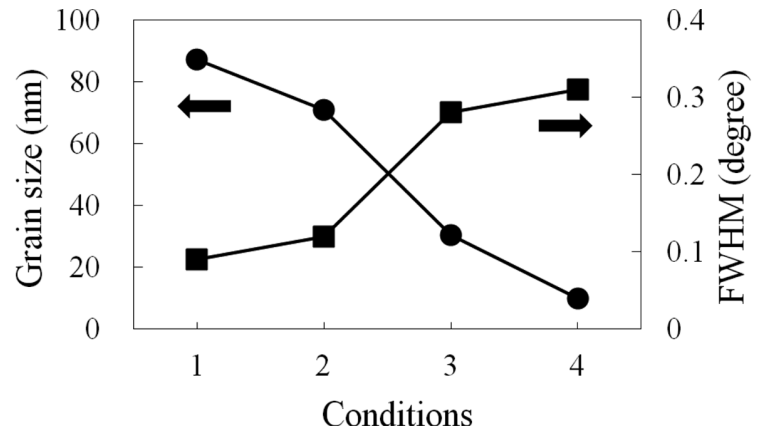

Fig. 3. FWHM of XRD diffraction peak and grain size of TiN films as a function of deposition parameters. 
가폭 크기로도 계산이 가능한데 일반적으로 반가폭 크기가 클수록 결정립 크기는 작아진다. 본 실험에 서 결정립 크기는 Scherrer법을 이용하여 계산하였고 반가폭이 증가할수록 결정립 크기는 감소하였다 ${ }^{14)}$. 그림에서 알 수 있듯이 듀티 싸이클 감소와 펄스 주파수 증가에 따라 $\mathrm{TiN}$ 코팅막의 결정립 크기는 $87.2 \mathrm{~nm}$ 부터 $9.8 \mathrm{~nm}$ 까지 거의 직선적으로 감소함을 알 수 있다. 따라서 $\mathrm{TiN}$ 코팅막의 미세구조를 제어 하는 기술로서 비대칭 펄스 $\mathrm{DC}$ 스퍼터법과 듀티 싸이클 및 펄스 주파수는 매우 중요한 공정변수임 을 알 수 있다.

이러한 TiN 코팅막의 결정립 크기의 나노화 원인 으로는 이온 에너지, 이온 플럭스, 잔류 불순물 및 결정학적 집합조직과 같은 복합적인 요소들의 영향 을 들 수 있다 ${ }^{15)}$. 본 연구에서는 성막 중 음전하를 띤 스퍼터 원자의 포격이 코팅막 안에 손상을 입혀 다수의 결함이 막 안에 형성되었다고 사료된다. 이 러한 결함의 밀도는 고에너지의 스퍼터 원자 때문 에 증가하게 되며 성막 중 기판 위에 반복적인 핵 생성을 유발시킨다. 불순물들은 입계에 석출하게 되 고 Zener drag로 인해 입성장이 제한되기 때문에 이는 나노결정질 TiN 코팅막의 형성 및 유지에 매 우 유리하다 ${ }^{16)}$.

\section{4 미세구조}

$\mathrm{DC}$ 및 펄스 $\mathrm{DC}$ 스퍼터법으로 제작된 $\mathrm{TiN}$ 코팅 막의 미세구조를 $\mathrm{FE}-\mathrm{SEM}$ 을 이용하여 관찰하였고 그 표면 사진을 그림 4에 나타내었다. $\mathrm{DC}$ 스퍼터 된 TiN 코팅막에서는 모두 평균크기 $100 \mathrm{~nm}$ 이상 의 주상구조의 다공성 결정립이 관찰된 반면 펄스 $\mathrm{DC}$ 스퍼터로 제작된 $\mathrm{TiN}$ 코팅막들은 듀티 싸이클 의 감소와 펄스 주파수의 증가에 따라 평균크기 $10 \mathrm{~nm}$ 이하의 치밀한 미세 결정립으로 변화되어감 을 알 수 있다. 높은 이온화도와 고밀도 플라즈마 를 얻을 수 있는 비대칭 바이폴라 펄스 $\mathrm{DC}$ 스퍼터 법을 이용한 결과 TiN 코팅막의 평균 결정립 크기 는 감소하였고 또한 미세구조는 치밀해졌다.

또한 본 연구에서는 성막 중 기판에 $\mathrm{DC}-100 \mathrm{~V}$ 의 바이어스 전압을 인가했기 때문에 $60 \sim 80 \mathrm{eV}$ 범 위의 이온 에너지 분포를 갖는 다수의 이온들이 기 판을 향해 이온 포격된 것으로 사료된다. 이러한 격 렬한 이온주입효과로 흡착원자의 에너지가 전달되 어 흡착원자의 이동도와 핵 생성 싸이트는 증가되 었고 결과적으로 결정립 크기의 감소와 주상 결정 립 사이의 기공이 제거되어 코팅막이 치밀화되었다 고 사료된다. 이러한 미세구조의 변화는 그림 7에 서 논의할 기계적 물성의 향상에도 기여한 것으로

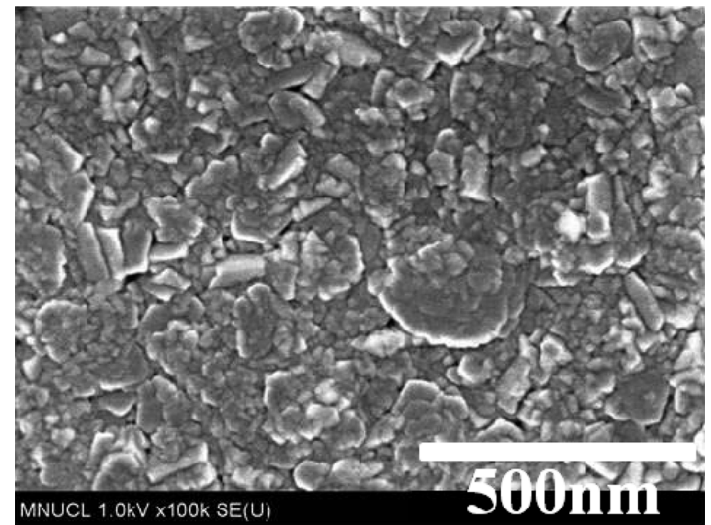

(a)

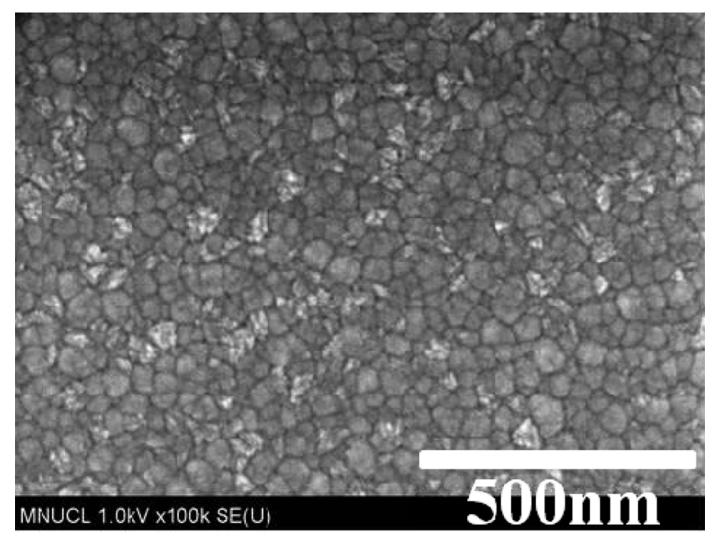

(b)

Fig. 4. Top surface view FE-SEM images of TiN films deposited at (a) condition 1 and at (b) condition 4.

사료된다.

\section{5 우선 배향성 및 잔류응력}

$\mathrm{DC}$ 스퍼터법 및 비대칭 펄스 스퍼터링법으로 제 작한 $\mathrm{TiN}$ 코팅막의 $\mathrm{X}$ 선 회절분석 결과를 그림 5 에 나타내었다. 모든 코팅막에서 (111)면과 (200)면의 피크가 관찰되었으며, 또한 코팅 중 펄스 플라즈마 에 따른 $\mathrm{TiN}$ 코팅막의 우선배향성을 알아보기 위해 각 회절 피크의 집합조직계수를 계산한 결과 (111) 면의 집합조직계수는 약 0.6 0.7, (200)면의 집합조 직계수는 약 0.2 0.3으로 코팅막 제작방법 및 공정 변수 차이로 인한 집합조직의 눈에 띄는 변화는 발 견되지 않았다. 그러나 비대칭 펄스 스퍼터법의 사 용과 코팅 중 듀티 싸이클의 감소 및 펄스 주파수 증가에 따라 $\mathrm{X}$ 선 회절분석 피크의 반가폭은 연속 적으로 감소함을 알 수 있다(그림 3 참조). 이는 $\mathrm{TiN}$ 코팅막의 미세구조의 나노화(결정립의 크기 감소) 를 의미하며 뒤에 토론할 그림 6의 $\mathrm{AFM}$ 결과와도 매우 잘 일치하고 있다.

코팅 중 듀티 싸이클 및 펄스 주파수가 $\mathrm{TiN}$ 코 팅막 내에 잔류응력에 미치는 영향을 알아보기 위 


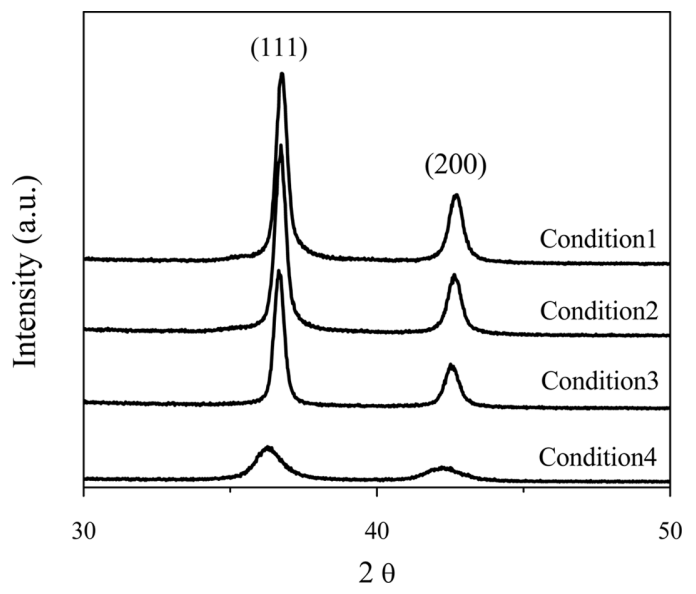

Fig. 5. XRD data of TiN films deposited using DC and pulsed DC sputtering.
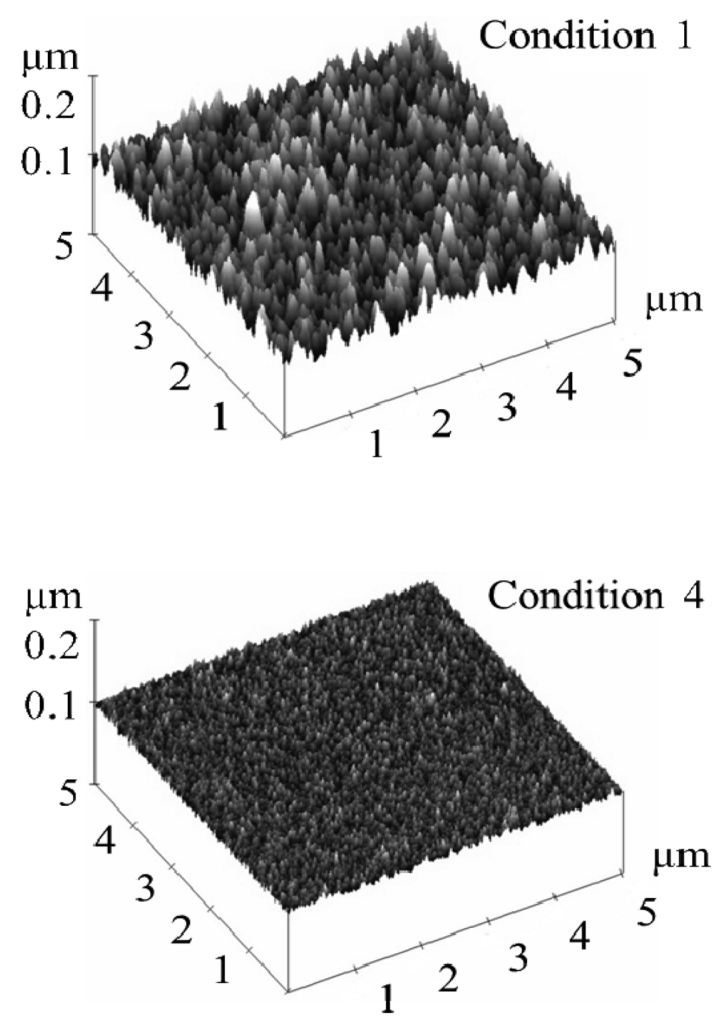

Fig. 6. AFM surface morphologies of TiN films deposited using DC and pulsed DC sputtering.

해 (111)면과 (200)면의 $2 \theta$ 분석결과를 표 2에 나 타내었다. 코팅 중 펄스 플라즈마 변수에 따라 $\mathrm{TiN}$ 회절 피크의 포지션 변화에 미치는 영향을 쉽게 표
현하기 위해 JCPDS 카드(\#6-0642)로부터 구한 TiN (111)면과 (200)면의 표준 $2 \theta$ 값을 함께 표시했다. 펄스 플라즈마 공정변수에 따라서 (111)면과 (200) 면의 측정 $2 \theta$ 값은 $\mathrm{TiN} \mathrm{JCPDS}$ 카드의 표준 $2 \theta$ 값 보다 감소함을 명확히 알 수 있다. 이러한 $2 \theta$ 값의 저각으로의 이동은 응력변화에 기인한다고 사료된다.

$\mathrm{PVD}$ 코팅에서 압축응력은 $\mathrm{Ar}^{+}$이온 포격에 의한 점결함 발생과 밀접한 관계가 있으며 코팅막의 단 결정과 같은 미세구조의 치밀화, 결정립 크기의 나 노화, 부착력 향상에 커다란 영향을 미친다 ${ }^{17)}$. 따라 서 본 실험에서 얻어진 TiN 코팅막 내부에는 상당 량의 잔류응력이 존재한다고 사료된다. 그 증거로 서 표 2의 $\mathrm{X}$ 선 회절분석 결과를 면밀히 관찰해보 면 $\mathrm{DC}$ 스퍼터법으로 제작된 $\mathrm{TiN}$ 막의 $2 \theta$ 값보다 펄스 플라즈마 공정변수를 사용한 TiN 코팅막이 낮 은 $2 \theta$ 값을 갖고 있음을 알 수 있는데 이는 코팅막 내부 압축응력의 증가를 시사한다.

\section{6 표면 거칠기}

코팅 중 듀티 싸이클과 펄스 주파수 변화가 TiN 코팅막의 3차원적 몰폴러지와 표면 거칠기에 미치 는 영향을 밝히기 위해 비접촉식 $\mathrm{AFM}$ 분석을 실 시하였다. 그림 6 은 $\mathrm{DC}$ 스퍼터법 및 펄스 스퍼터 법으로 제작한 $\mathrm{TiN}$ 코팅막의 3차원 표면 미세구조 를 나타내고 있다. 코팅 중 듀티 싸이클과 펄스 주 파수가 TiN 코팅막의 RMS (Root Mean Square) 표 면 거칠기에 미치는 결과를 비교하면 매우 흥미로 운 점을 발견할 수 있는데 펄스 스퍼터링법으로 제 작한 $\mathrm{TiN}$ 코팅막의 표면이 종래의 $\mathrm{DC}$ 스퍼터링법 으로 코팅한 $\mathrm{TiN}$ 코팅막보다 평탄하다는 점이다. 예를 들면 연속적인 $\mathrm{DC}$ 스퍼터링법으로 제작한 $\mathrm{TiN}$ 코팅막의 RMS 표면 거칠기는 $12.3 \mathrm{~nm}$ 인 반면 듀 티 싸이클 $50 \%$ 와 펄스 주파수 $50 \mathrm{KHz}$ 를 인가하여 제작한 $\mathrm{TiN}$ 코팅막의 RMS 표면 거칠기는 $3.3 \mathrm{~nm}$ 이다. 이러한 비대칭 펄스 스퍼터법으로 제작된 TiN 코팅막의 평탄한 표면 몰폴러지의 형성 원인으로는 마이크로 아크 생성에 따른 이온전류 밀도와 핵 생 성 밀도의 증가를 들 수 있다.

\section{7 나노 경도}

$\mathrm{DC}$ 스퍼터법 및 비대칭 펄스 스퍼터링법으로 제

Table 2. XRD data of TiN films for DC and pulsed DC sputtering

\begin{tabular}{|c|c|c|c|c|c|c|c|c|c|c|}
\hline \multirow{2}{*}{ TiN } & \multicolumn{10}{|c|}{ Peak position } \\
\hline & \multicolumn{5}{|c|}{ (111) } & \multicolumn{5}{|c|}{$(200)$} \\
\hline Duty cycle (\%) & 100 & 95 & 75 & 50 & standard & 100 & 95 & 75 & 50 & standard \\
\hline $2 \theta\left(\left(^{\circ}\right)\right.$ & 36.78 & 36.74 & 36.73 & 36.40 & 36.83 & 42.72 & 42.69 & 42.49 & 42.21 & 42.64 \\
\hline
\end{tabular}




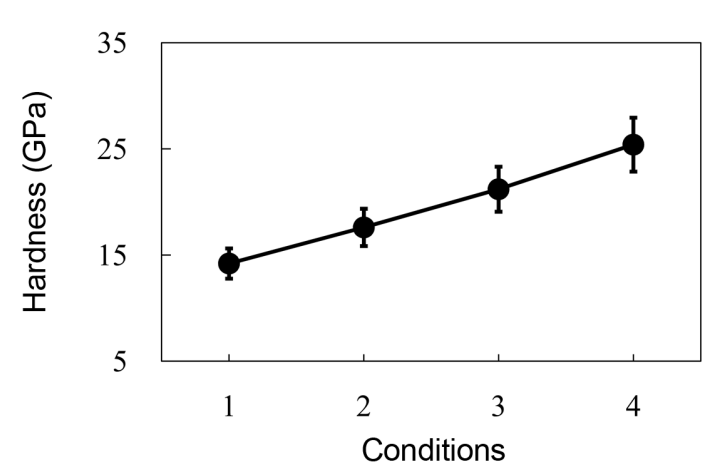

Fig. 7. The nanoindentation hardness of TiN films prepared at DC and pulsed DC sputtering.

작한 $\mathrm{TiN}$ 코팅막의 기계적 경도를 나노인덴테이션 장비를 이용하여 측정하였고 이를 그림 7 에 나타내 었다. 본 연구에서 코팅막의 나노 경도 측정을 위한 입자의 인가하중은 $5 \mathrm{mN}$ 으로 고정했으며, 압입깊이 가 얕을수록 측정된 경도값이 증가하는 경향을 보 이는 인덴테이션 크기 효과 ${ }^{18)}$ 를 배제하기 위하여 전 체 막 두께의 $1 / 10$ 지점으로 평균화하였다. 본 연구 결과에서 종래의 $\mathrm{DC}$ 스퍼터링법보다 비대칭 펄스 $\mathrm{DC}$ 스퍼터링법으로 제작한 $\mathrm{TiN}$ 코팅막의 나노 경 도값이 높음을 알 수 있다. 이러한 TiN 코팅막의 나 노 경도는 듀티 싸이클의 감소와 펄스 주파수의 증 가에 따라 증가함을 알 수 있는데 예를 들면 듀티 싸이클 $50 \%$ 와 펄스 주파수 $50 \mathrm{KHz}$ 에서 제조된 $\mathrm{TiN}$ 코팅막의 나노 경도값은 약 $26 \mathrm{GPa}$ 로 $\mathrm{DC}$ 스퍼터법 으로 제조한 $\mathrm{TiN}$ 코팅막의 나노 경도값 $14 \mathrm{GPa}$ 보다 약 1.9 배 증가함을 알 수 있다. 이러한 펄스 $\mathrm{DC}$ 스 퍼터법으로 제작된 $\mathrm{TiN}$ 코팅막의 나노 경도의 상승 은 고이온화 고밀도 플라즈마의 생성으로 인한 결 정립 크기의 감소에 따른 미세구조의 치밀화, 기판 바이어스 전압인가에 따른 높은 이온포격효과 및 압 축응력의 상승에 주로 기인한다고 사료된다.

\section{4. 결 론}

본 연구에서는 비대칭 바이폴라 펄스 $\mathrm{DC}$ 스퍼터 링법으로 나노결정질 $\mathrm{TiN}$ 코팅막을 제조하였으며, 타겟에 인가되는 듀티 싸이클과 펄스 주파수에 따 른 코팅막의 미세구조, 집합조직 및 기계적 특성 등 을 조사하였다. 듀티 싸이클 $50 \%$ 와 펄스 주파수 $50 \mathrm{KHz}$ 가 인가되었을 때 평균 결정립 크기는 약 $9.8 \mathrm{~nm}$ 로 가장 치밀한 코팅막 성장을 나타내었으며, $3.3 \mathrm{~nm}$ 의 매우 낮은 RMS 표면 거칠기를 나타내었
다. X선 회절분석 결과, 주로 (111)면의 집합조직 발달이 관찰되었으나 (111)면과 (200)면 모두 $2 \theta$ 값 은 감소하였고 이는 $\mathrm{TiN}$ 코팅막 내 압축응력이 증 가함을 시사한다. 또한 나노 경도값은 약 $26 \mathrm{GPa}$ 로 $\mathrm{DC}$ 스퍼터법으로 제조한 $\mathrm{TiN}$ 코팅막의 나노 경도 값 $14 \mathrm{GPa}$ 보다 약 2 배 증가함을 알 수 있다. 따라 서 듀티 싸이클과 펄스 주파수와 같은 펄스 플라즈 마 변수를 조절하여 종래의 $\mathrm{DC}$ 스퍼터링보다 우수 한 미세구조, 결정구조 및 기계적 특성을 갖는 나 노결정질 TiN 코팅막을 제조할 수 있다.

\section{참고문헌}

1. F. Vaz, J. Ferreira, E. Riberio, L. Rebouta, S. LancerosMendez, J. A. Mendes, E. Alves, Ph. Goudeau et al., Surf. Coat. Tech., 191 (2005) 317.

2. A. Kagiyama, K. Terakadoa, R. Uraob, Surf. Coat. Tech., 397 (2003) 169.

3. J. W. Uhm, H. T. Joen, Jpn. J. Appl. Phys., 40 (2001) 4657.

4. W. D. Sproul, J. E. Greene, J. A. Thornton (Eds), Phys. Chem. Protective Coat., American Inst. Phys., (1986) 50.

5. N. Y. Kim, Y. B. Son, J. H. Oh, C. K. Hwangbo, M. C. Park, Surf. Coat. Tech., 156(160) (2000) 128.

6. Y. S. Kim, H. Jone, Y. D. Kim, J. Kor. Phys. Soc., 37 (2000) 1045.

7. C. Rebholz, A. Leyland, P. Larour, C. Charitidis, S. Logothetidis, A. Matthews, Surf. Coat. Tech., 116(119) (1999) 648.

8. J. Sellers, Surf. Coat. Tech., 98 (1998) 1245.

9. H. D. Ko, C. S. Lee, W. P. Tai, S. J. She, Y. S. Kim, J. Kor. Ceram. Soc., 41(6) (2004) 476.

10. J. H. Kim, J. K. Lee, J. H. Ahn, J. Kor. Ceram. Soc., 38(1) (2001) 61.

11. W. D. Sproul, J. Vac. Sci. Tech., 51 (1998) 641.

12. J. Sellers, Surf. Coat. Tech., 98 (1998) 1245.

13. J. W. Lee, S. K. Tien, Y. C. Kuo, J. Elec. Mater., 34 (2005) 1484.

14. B. D. Cullity, S. R. Stock, Element of X-ray Diffraction, Prentice-Hall Inc., 3rd (2001) 167.

15. I. Petrov, P. B. Barna, L. Hultman, J. E. Greene, J. Vac. Sci. Tech. A, 21 (2003) 774.

16. N. Maazi, N. Rouag, J. Cryst. Growth, 243 (2002) 361.

17. I. Petrov, L. Hultman, U. Helmersson, S. A. Barnett, J. E. Sundgern, J. E. Green, Thin Solid Films, 169 (1989) 299.

18. S. Kim, D. M. Kim, S. Kang, H. J. Kim, J. Kor. Ceram. Soc., 46(2) (2009) 116. 